\title{
THE FRENCH LEFT-WING RADICALS
}

\author{
THEIR VIEWS ON TRADE UNIONISM, I $870-1898^{1}$
}

During the first three decades of the Third Republic there appeared a group of left-wing republicans who became known as RadicalSocialists. As a group they had many ideas in common and tended to vote on many issues with a rather high degree of unity. However, a careful study of their voting record allows three divisions to be made among them. On the extreme Left were the hard core RadicalSocialists (HCRS). They are so designated because their voting record attained a total of about $90 \%$ on bills and orders of the day of an advanced social nature. Somewhat less consistent were the RadicalSocialists (RS) who attained at least $75 \%$. Among the former were deputies whose stand for reform was about as consistent as that of the average Socialist. Some of the most famous were Georges Clemenceau, Camille Pelletan, Georges Perin, Tony Révillon, Désiré Barodet, Henri and Félix Mathé, Armand Duportal, Félix Cantagrel, Camille Raspail, Sigismond Lacroix, Ernest Lefèvre, Martin Nadaud, Stéphan Pichon, Emile Chautemps and Marius Chavanne. Among the RadicalSocialists were Antoine Achard, Jules Baulard, Henri Maret, Germain Casse, René Goblet, Paul Doumer, Edouard Lockroy, Gustave Mesureur, Louis-Bernard Montaut, Michel Salis, Emile Brousse, Jules Lasbaysses, Roque de Fillol, Gustave Hubbard, and Benjamin Raspail. Another group, somewhat peripheral to the present study but included in order to round it out, were the social Radicals (SR), or Radicaux de Gauche, as they called themselves after $188 \mathrm{r}$. Their voting record averaged about $60 \%$. The term "left-wing Radicals" includes all the above categories. The moderate or orthodox Radicals were really advanced liberals as regards social legislation, and do not form part of the groups examined in this essay.

The above classifications are not based exclusively on the quantity of votes, but also on their quality. Each issue must be weighed. For

1 The research for this article was made possible by grants from the University of Buffalo and the Social Science Research Council. 
example, a vote against a tariff on wheat which free trade liberals opposed, must not be put in the same category as a vote in favor of the nine-hour workday, which liberals and orthodox Radicals, as well as many social Radicals, denounced as socialism. In addition, there existed no clear cut delineation between hard core Radical-Socialists and Radical-Socialists. A deputy in one legislature might meet the requirements of the hard core level, but could in the next legislature fall below it, or vice versa. This was particularly true between the I 870 's and I 880 's because social measures were more frequently introduced. Some extremists of the first decade became fairly moderate in the next decade, largely because more and more bills called for extensive governmental regulation of the economy. It was one thing to favor legal recognition of trade unions, but another to vote for the prohibition of night work. Jules Roch and Yves Guyot are examples of this tendency. For this reason all Radical-Socialists shall be classified as a group, though it is important to bear in mind that more than half were socialisants.

The following chart gives an estimate of the numerical strength of the left-wing Radicals between 1877 , when they began to distinguish themselves from the Gambettists, and 1898 , the beginning of the Dreyfus Case which markedly affected their movement:

$\begin{array}{lccccc} & \text { I 877-8 I } & \text { I 88 I-85 } & \text { I 885-89 } & \text { I 889-93 } & \text { I 893-98 } \\ \text { HCRS } & 21 & 37 & 32 & 21 & 29 \\ \text { RS } & 31 & 14 & 21 & 16 & 19 \\ \text { SR } & \text { I3 } & 21 & 26 & 29 & 27 \\ \text { Total } & 65 & 72 & 79 & 66 & 75\end{array}$

Of course these totals vary slightly during each legislature, due to resignations and death. The left-wing Radicals were strongest in the legislature of $1885-89$, weakest in those of $1877-81$ and $1889-93$. It appears that Boulangism had an adverse effect. The fear created by the General certainly moderated the extreme Left vote, and in doing this, did delimit the number of deputies ready to cast a white ball for advanced reforms. Therefore Boulangism brought about a decline in the number of deputies here classified because our classification is based on voting records. There was, however, not only a decline in momentum, but also an absolute one in numerical strength. There were sixteen hard core Radical-Socialists not returned in 1889 , and only nine new ones chosen to replace them. The losses were qualitatively serious; no longer on the extreme Left were some of the most determined reformers: Achard, Bourneville, Brelay, Brialou, Crémieux, La Forge, Frébault, Lacroix, Lafont, Maurel, Perin, Préveraud and 
Simyan. The losses among the Radical-Socialists were not quite as serious.

The deputies studied in this essay formed only a rather loose parliamentary group, not a political party. The Radical-Socialists issued manifestoes from time to time, but they enjoyed no organic unity. In consequence they voted as principles, conscience or local pressures dictated. The specific motives behind many choices are difficult to uncover; however, several general conclusions may be drawn from the left-wing vote as a whole. The thesis of this article is based on these conclusions.

This thesis holds that before I 900 the left-wing Radicals were more advanced in their social philosophy and action than many historians of the Third Republic would lead one to believe. A common statement among these historians was that the men in question were neither radical nor socialist. By the I920's this assertion was probably true. However, it has been taken up by writers and applied to the preWorld War I period, with the result that several quite prominent scholars, looking over the first thirty years of the Republic, have concluded that republicans of all shades were disinterested in social problems. Apart from the Socialists, only social Catholics, following Albert de Mun, took up the cause of the workers. ${ }^{1}$ Our contention is that there existed on the left of the republican movement a group of politicians who were vitally concerned with labor problems and whose proposals were far more realistic in the French context than those of the social Catholics. As advanced republicans they were certainly active in defense of the Republic. They did not, however, allow their political considerations to obscure the need for social reform. On the contrary, they consistently preached that the Republic would survive only if it implemented a vast program of reform.

This article deals with only one aspect of their total social program, trade unionism and industrial relations: it is a study of their views on labor unions (syndicats ouvriers professionnels), and of their efforts on behalf of labor organization.

$$
* *
$$

The left-wing Radicals were strongly committed to trade unionism. Of course so were most republicans. However, advanced Radicals considered labor organizations a necessary part of the integral democracy they desired. It must be kept in mind that the average

- François Goguel, La politique des partis sous la Troisième République (Paris, 1946), p. 67. J. Chastenet, Histoire de la Troisième République (Paris, I954), II, 23-24. 
left-wing Radical looked toward political, administrative and judicial democracy. Nearly every agency not based on the elective principle was suspect in his eyes. And during the first thirty years of the Third Republic he was constantly demanding a purge of all nonrepublicans from public positions. Naturally then, he was inclined toward some sort of industrial democracy. Just as the division of land made for rural democracy the organization of workers along professional lines, with each union electing its leaders, would introduce more democracy into the factory. There was no need for large scale nationalization. Craft unions would constitute the democratic element in the formulation of policies affecting labor. In this way, the new industrial society would become a more solid democratic base for the democratic state. Through their unions, workers would play an important role in France and would become even more intimately bound to the Republic. Consolidation of the government, the preservation of it from clerico-monarchist plotters, the staffing of its posts with men faithful to it, the education of a new generation in republican ideas, these problems stood high on the agenda of all Radicals. For the average Radical, such political issues stood uppermost. For the leftwing Radicals, however, political issues could not be separated from social and economic ones. Republicanism and syndicalism must go hand in hand. Louis Asseline wrote in Le Rappel: "Or, quelle est la forme gouvernementale qui peut décréter législativement cette pleine liberté de réunion et d'association, si ce n'est la forme politique la plus avancée? Et quelle est la forme politique la plus avancée, si ce n'est la République radicale? La République radicale est l'instrument nécessaire de la réforme sociale et, pour arriver à l'une, il faut établir et garder l'autre dans sa plénitude." ${ }^{1}$ If the working class were not won over to the government, there would be no true republic. The left-wing broke from Gambetta's leadership because "non seulement la question sociale existe, mais elle seule existe". ${ }^{2}$ Camille Pelletan, a leading hard core Radical-Socialist, said the same before the Chamber of Deputies: "Je constate seulement un fait, c'est que la Chambre, nommée sur un programme de réformes, n'en a encore abordé aucune." 3

Now the Radical-Socialists did not deny that significant progress had been made in social improvement, but they were convinced that

1 Oct. 7,1876 , p. 1, col. 2.

2 Le Radical, Nov. 4, I88I, p. I, col, 4.

3 Journal officiel. Débats parlementaires. Chambre des Députés. March 31, 1882, p. 469. Henceforth cited as $\mathrm{J}$. O. The dates refer to the sessions. 
among the workers, the "disinherited" as they called them, there was more suffering than happiness, far more poverty than well-being. Oftentimes their press came out with vivid descriptions of this poverty. And as deputies they frequently demanded investigations of the conditions of labor. To improve conditions they participated actively in the elaboration of various forms of factory legislation, and their schemes, defeated generally by the moderate republican majority, would have taken France well along the road to the welfare state. But while they favored a certain amount of state intervention, most of them agreed that the immediate improvement of factory conditions depended on an active trade union movement.

During the $1870^{\prime}$ 's the left-wing Radical press was indefatigable in urging the workers of France to unite. The word solidarite appeared often in this literature. But this call for solidarity grew out of the earlier nineteenth century radical tradition, that of the secret societies of the 1830 's, that of 1848 , hardly out of the vague ideal put forward by Léon Bourgeois in the mid-r 890's. Placed among the men we are dealing with here, Bourgeois was a moderate thinker. His voting record on social issues was a conservative one compared to theirs. Unlike their orthodox colleagues, the Radical-Socialists revealed a dynamism, a sense of urgency in their call for labor unity. Probably they remembered how easily the Second Republic had been overthrown while unorganized workers simply watched. The RadicalSocialist press, Le Rappel of the Hugo's, La République française of Gambetta (until the later I 870's), Le Radical of Maret, and La Justice of Clemenceau, urged their working-class readers to form trade unions. Almost without failure they held up as an ideal the large, consolidated English craft unions. Gambetta's journal explained that a trade union was not a revolutionary society, nor was it a co-operative. It was, rather, a union of workers in the same or related crafts for the purpose of strengthening each member's position when dealing with management. English trade unions, it went on, have grown powerful and respectable because they are based on the mottos, "All men are brethren" and "United we stand, divided we fall", translated by the paper as "L'union fait la force". 1

Martin Nadaud, who had lived as an exile in England for about twenty years, was particularly active in urging French workers to follow the example of the British. Therefore he argued that organization was not enough, a well-stocked treasury is just as important. Money is the nerve of war, and an association "sans une forte réserve en capital est complètement inutile aux travailleurs dans les nations

1 République française, March 9, 1872, p. 3, cols. I-2; Aptil 4, 1872, p. 2, col. I; April 7, 1872, pp. 2-3. 
vouées à l'industrie, où les crises sont si fréquentes, et où la concurrence devient chaque jour plus pernicieuse." French workers also must undergo a psychological change: "Je voudrais bien connaitre le moyen de faire passer dans les habitudes du peuple français cet esprit d'ordre, de persévérance et de ténacité, qui est la qualité dominante de John Bull." Character is as important as unity: "quand les travailleurs ont un but commun, bien tracé, bien défini, la volonté et le caractère jouent un rôle immense dans nos sociétés, c'est ce rôle de la volonté humaine qui limite la part que les maitres donnent, et que les ouvriers reçoivent." 1 The views of Nadaud strongly influenced the labor program of his colleagues in the Chamber and it is highly probable that the post-I900 disenchantment of the Radicals with labor resulted partly from the failure of French workers to organize strong unions.

Unity and an adequate treasury became a constant theme in the Radical press. Each journal offered a special column devoted to labor. In it appeared information about older or newly founded trade unions, dates of their meetings and agenda, and a good deal of practical advice. Above all the workers were urged to organize. "La masse des capitaux, l'exploitation effrénée du travail se concentrant en quelques mains, obligent les travailleurs à s'unir, à se souder, pour résister à l'écrasement." 2

Probably as influential as Nadaud was Lucien Pauliat, editor of the labor column, "Mouvement ouvrier", in Le Rappel. He sought to dispel the fear that trade unions were absolutely illegal. He consulted François Dupont, an oldline republican lawyer and co-worker of Louis Blanc in the I 840's. Organization was possible, he assured, despite certain articles of the code prohibitive of associations either of employers or of workers. Both police and judiciary tolerated these associations provided they were involved in purely craft matters. The workers, he went on, ought not to limit their activities to local affairs; they should attempt regional and national federation in order to consolidate their strength. Above all, every chambre syndicale must have "une caisse bien fournie." "Elle doit donc s'imposer le plus qu'elle peut ..." Joseph Barberet also wrote in Le Rappel. His call was to the worker's sense of duty, or better, to the worker's sense of class obligation. His method was that of the case history with individual examples. There was the piano maker who would not sign up with

\footnotetext{
1 Martin Nadaud, Sociétés ouvrières (Paris, I 873), pp. 104-10.

2 La Justice, May 22, 1880, p. I, cols. 5-6.

3 Le Rappel, July 4, I871, p. 3, cols. I-2; July I 8, I 872, p. 3, col. 5; Nov. I3, I872, p. 3, cols. 4-5; see also his brochure Associations et chambres syndicales ouvrières (Paris, 1873 ), pp. $34-35,81 \mathrm{ff}$.
} 
the union, but who finally had to seek its aid in a suit against his employer. Now he joined and recognized "son devoir envers le principe de solidarite". Barberet also cultivated the notion that the present generation must accept the burden of organization and struggle in order that the next generations would be better off. ${ }^{1}$

The Radical press appealed both to the material interests of the workers and to a higher ideal: a society based on solidarity. Syndicalism had as its immediate goal higher wages, a shorter day, better conditions; but in the future, it would produce a new society in which co-operative production would replace capitalist production, and the salary system disappear. Here of course was the ideal which set the Radical-Socialist off from both the social and orthodox Radicals; the ultimate goal of the former was neo-socialist. Yet, all agreed that the prime force behind labor's improvement must be labor itself. In the $1870^{\circ}$ 's especially, the Radical press was at one with the dominant sentiment of ouvrierisme, that the workers must go it alone. Expecting much from labor, and only hostility from the promonarchist state, many left-wing Radicals believed that the state's role should be negative: to clear away legal and administrative obstacles to organization and solidarity, to reform taxes, to provide education. ${ }^{2}$ Charles Longuet aptly expressed this theme in La Justice: "C'est donc à l'initiative des intéressés qu'il faut constamment faire appel. C'est leur énergie qu'il faut provoquer ..." This could be done by public discussions, by bringing to light pertinent data bearing on social conditions, by formulating plans of action. As long as workers are not organized, he pursued, they cannot find their natural leaders; they will follow demagogues or reactionaries posing as social reformers. ${ }^{3}$ Undoubtedly Longuet had in mind social Catholics such as Albert de Mun.

The Radicals drew a sharp distinction between syndicats ouvriers which they favored, and corporations as favored by de Mun. Certainly they put no faith in, were indeed highly distrustful of, corporations mixtes, associations combining employers and laborers. They really were severe critics of any ideology preaching class struggle, yet they almost instinctively sided with the worker against his employer. And de Mun's corporatism seemed to them a clerico-royalist trap to ensnare workers. This was the line of argument taken by Edouard Lockroy during debate on the trade union bill: "Ce qu'on nous demande, en réalité, c'est la faculté, pour certains hommes, pour les

1 Le Rappel, Jan. 16, 1875, p. 3, col. 4; Jan. 19, 1875, p. 3, col. 3.

2 La Justice, May 22, I880, p. I, col. 3 ; Sept. Is, I880, p. 1, cols. 5-6.

3 Ibid., Oct. 12, I880, p. I, cols. 3-4. 
capitalistes chrétiens, pour les chefs du parti clérical ('Oui! - c'est cela!' à gauche), pour ceux que j'appellerai les bailleurs de fonds du trône et de l'autel (rires approbatifs) de grouper autour d'eux des patrons qu'ils auraient à leur dévotion et des ouvriers qu'ils auraient à leur solde . . . C'est de créer des associations privilégiées auxquelles on donnerait des droits qu'on refuserait aux syndicats professionnels laĩques; auxquelles on donnerait des libertés qu'on refuserait aux syndicats professionnels laïques, de façon à former une espèce de puissance sociale indépendante, qui deviendrait bientôt toute puissante, écraserait toute concurrence, monopoliserait le travail, restaurerait la main-morte et serait mise tout entière au service de l'Eglise et entre les mains du clergé ('Trés bien' . . et applaudissements nombreux à gauche)." 1

Charles Floquet continued the attack on June 19, to be followed by Clemenceau who compared French monarchists to slave owners in the United States after the Civil War. As for their paternalism, "l'ouvrier repousse et repoussera toujours vos présents, car il affirme, en même temps que son droit de vivre, sa complète indépendance, sa liberté." 2

During the period under study here the left-wing Radicals hardly considered the issue of compulsory union membership, or anything resembling the closed shop or union shop. They believed that workers, once protected by the law from discriminatory practices by employers would hasten to join a trade union. What was needed, then, was new legislation, first to legalize unions, then to protect them from hostile employers.

$$
* *
$$

The Radical-Socialists took an active part in parliamentary debates dealing with the legalization of trade unions. Traditionally, all republicans were strongly pledged to full freedom of association, and in I 848 when they exercised some influence over the Provisional Government, acts restrictive of association were not applied. Among these was the Le Chapelier law of 1791 . It had been passed in order to abolish the guilds but it also prohibited trade organizations of any sort. Unfortunately it was applied principally against workers' unions. With the weakening of the radical element in the Second Republic, restrictive legislation was enforced again. However, in 1864 and 1868, Napoleon III, in his bid for labor support, instituted legislation tolerant of labor coalitions and public meetings. The Commune of

1 J.O., June 12, 1883, p. 1283 . See also La Justice, Feb. 4, I88o, p. I, cols. 3-4.

2 J.O., June 19. 1883, pp. I352-56, 1359-6o. See also Le Radical, Feb. 19, r893, p. I, col. 4 . 
I87I provoked a reaction; unions were dissolved by an oppressive military regime and in 1872 , despite the opposition of some Radicals, the Workingmen's International was declared illegal.

It has already been noted that even during the height of this reaction, the Radical press continued to favor trade unionism and to encourage workers to unite. Sigismond Lacroix, among others, attacked the government for tolerating employers' unions while disallowing those of workers. He stood in defense of the law of 1864 which, he believed, tolerated both peaceful strikes and labor unions. He recognized that this act left the unions at the mercy of the state. ${ }^{1}$ Therefore he and his colleagues, calling themselves Intransigent Radicals, stood firmly in favor of a Jacobin constitution including full freedom of association. Led by Louis Blanc, Clemenceau and Camille Pelletan, this group organized itself in opposition to Gambetta as he ceased to be intransigent. To emphasize their concern for social reform, they began calling themselves Radical-Socialists, in imitation of their leaders who used this denomination during the elections of 1876 .

1876 was an important year for the extreme Left. The first national labor congress was held and moderation was its keynote. In addition, about fifty left-wing Radicals won seats in the Chamber of Deputies during the March elections. In July, Edouard Lockroy, one of them at this date, introduced a bill to legalize professional unions of employers and of workers. He argued that both types of craft unions were tolerated and therefore they existed in fact. Both are useful, rendering services of various sorts to industry, and most important, they have both proven that their existence is compatible with social order. The law of I79I was needed when it was put on the books; it destroyed the guilds as well as the monopolistic spirit of the Old Regime; it was "juste de briser ces barrières, d'émanciper ces castes, de rendre le travail accessible à tous." But today this law is baneful given the great increase in the number of workers, and their concentration in factories. "La liberté individuelle ne suffit plus, ni à l'ouvrier, ni au patron, pour lutter sur le champ de bataille industriel, ainsi transformé et agrandi. Il faut y joindre la liberté d'association." Thus, labor and capital could, by means of their organizations, carry out the objectives they had in common. ${ }^{2}$

Lockroy's project, however, was widely attacked by the workers' congress in Paris during October. The flaw in the bill was this: in

1 Le Radical, Dec. 15, I 871, p. I, cols. 3-4.

2 See this speech in Le Rappel, July 19, 1876, p. I, col. 6. This paper strongly supported Lockroy, as did the shortlived organ of Louis Blanc, Homme Libre, Nov. 14, 1876, p. 1, col. 1 . 
order to acquire legal recognition, it was necessary to deposit with administrative officials the names and addresses of all members of the union. Delegates of the machinists' union called this "une loi de police d'un nouveau genre". ${ }^{1}$ The Lockroy bill failed. Undoubtedly the adverse comments put forward by the labor congress awakened in many Radical-Socialists the desire to go beyond Lockroy's tame measure. Rather than sponsor a special bill to legalize only trade unions, they rallied to the idea of a general bill granting full freedom of association, which would include trade unions.

This was the program taken up by them during i 880 when a new project was brought forward, this time by the government. Charles Floquet, a moderate Radical by now, presided the committee which studied it, and Allain-Targé, a Gambettist, reported it on November $2 \mathrm{I}$ and March 15, I88I. The original bill was modeled on that of Lockroy; the committee, however, decided that not the entire membership, but only the chief officers, must make known their names to the government. The bill was not one on association, but specifically for professional unions whether of employers or workers or both.

By $1880-81$, practically no deputy in the Chamber was opposed to legal trade unionism. The debates therefore dealt with specific articles. The extreme Radical left was represented by Félix Cantagrel, an old line Jacobin and friend of Louis Blanc. These intransigents opposed the first article because, while it granted legality to professional unions, it did not provide for full freedom of association. Cantagrel explained that there were two ways to make a law. "Le premier procédé, messieurs, consiste à faire une loi générale, à agir en vertu d'une vue d'ensemble. Ce procédé, c'est le bon; il aboutit à une loi de droit commun qui évite au législateur les contradictions, les réglementations, les limitations dont j'aurai à parler tout à l'heure. Le second procédé consiste à prendre un point dans une grande législation, comme celle de l'association, par exemple, et à le travailler à part; c'est ce qu'ont fait le Gouvernement en proposant son projet et la commission en acceptant cette base. Je prétends que ce procédé est le mauvais." He went on to condemn the view that one should begin by legalizing trade unions and then move toward a general law on associations. The cabinet had stated that the present bill would form a chapter in the future general bill. "Dans une loi générale d'association, les mots de syndicats professionnels ne seraient même pas prononcés; on dirait: Toute association jouira de

1 Jean Montreuil, Histoire du mouvement ouvrier en France (Paris, 1946), p. I 3 r. Emile Levasseur, Questions ouvrières et industrielles en France (Paris, 1907), p. 476. 
tels avantages, à la condition qu'elle remplisse telles formalités ... S'il est vrai que vous ne concédiez, sans avoir besoin de demander l'autorisation au Gouvernement, cette faculté qu'aux syndicats professionnels, vous le voyez, ce serait l'inégalité sociale et l'arbitraire légal que vous établiriez . . . Il y a là une inégalité dont je ne me plains pas absolument; je vais vous dire pourquoi. Votre loi, une fois votée, soulèvera des réclamations nombreuses de la part de toutes les personnes qui voudront créer des écoles professionnelles d'apprentissage, des bibliothèques populaires, des sociétés de propagation pour l'instruction primaire, réclamations telles que vous serez obligés, tout au moins, si vous croyez ne pas devoir faire une loi d'association générale, de faire une loi pour chacune des sociétés qui viendront vous réclamer la liberté que vous donnez aux syndicats professionnels ...

Est-ce une situation légale souhaitable? Vous ferez donc mille lois pour donner la liberté à mille sociétés qui vous la demanderont et qui y auront autant de droits que les syndicats professionnels?

Qu'on ne s'y trompe pas: je ne combats pas les syndicats professionnels et la liberté que vous voulez leur donner; je trouve qu'on ne leur donne pas tout ce qu'on devrait leur donner . . ."1 1

Cantagrel now proposed an amendment to article $\mathrm{I}$, so as to eliminate the words here included in parentheses: "La loi du 14 et 17 juin I 791 et les dispositions des articles 4I 4, 4I 5 et 4 I 6 du code pénal sont abrogées. Les dispositions des articles 29I, 292, 293, 294 du code pénal, la loi du ro avril 1834 et l'article 2 du décret des 25 mars et 2 avril 1852 cesseront d'être applicables aux syndicats professionnels (constitués et agissant en conformité des prescriptions de la présent loi)." 2

Charles Beauquier agreed with Cantagrel. He wanted to see the rights of association, of meeting, of free press written into the Constitution, as they had been in 1848 . 'L'Etat, à mon avis, n'a pas le droit d'intervenir dans le règlement des intérêts, pas plus qu'au point de vue des opinions." Therefore he proposed the following amendment: "Les syndicats professionnels sont des associations composées de plus de vingt personnes et des professions similaires. Ils pourront se constituer librement sans l'autorisation du Gouvernement. Dans les centres de population au-dessous de vingt mille âmes, ces associations pourront être formées par des ouvriers exerçant des professions même non similaires." He went on to insist that the workers were better off under the existing regime of toleration; if

1 J.O., May I 7, I 881 , pp. 910-1 2.

2 Ibid., p. 917. 
their unions were not civil personalities at least they did not have to register with the local authorities. ${ }^{1}$

The most effective opposition to these amendments came from another Radical-Socialist, Martin Nadaud. He had been a long time in exile in England. What he wanted was a "practical" bill. He therefore denied that the present regime of toleration would be preferable to the one provided for in the bill. Delay, he argued, would be fatal, for the French, unlike the English, quickly lose interest in these issues. The bill must be passed while the public is still aroused. These amendments, therefore, are not in the interests of the workers. Moreover, the bill opens the door to legal unionism. Here is the step to be accomplished at this moment; Radicals should recognize that a general law on associations will not give workers the force needed for their defense against capitalists. He also differed from Beauquier in his rejection of general associations. Workers of different crafts cannot unite effectively, their interests being too divergent. "Il faut absolument qu'il y ait séparation entre les chambres syndicales et le principe d'association." 2 Nadaud was speaking as an old labor organizer; his opponents as Radical politicians. To support Nadaud, Allain-Targé pointed out that a committee, presided by Louis Blanc, was preparing a bill on the right of association.

Both amendments were defeated; only that of Cantagrel underwent a scrutin public, 168 votes for it, 25 I against. Many Catholic Royalists voted in its favor, hoping to win a measure of freedom for clerical associations and guilds. Most Socialists voted for. The Radical vote was splintered. Fourteen left-wing Radicals, half of whom were Radical-Socialists, voted against Cantagrel, either out of fear that his amendement would favor clerical associations, or out of the desire to follow Nadaud. Twenty-five out of about fifty-two Radical-Socialists voted for it, and most of these were hard core. The remainder abstained.

After this defeat, the Radicals grew aware that article I of the new bill would bring into existence two types of unions: those which were willing to register and those which were not. Cantagrel once more went up to the rostrum, this time to inquire about the future status of unregistered unions. Both Allain-Targé and Floquet assured him that they would continue to exist under the regime of tolerance, that is, "sous le droit commun". ${ }^{3}$ Allain-Targé pointed out that the

1 Ibid.

2 Ibid., pp. 918-19.

3 Ibid., pp. 92 I-24. 
new bill marked a great improvement over the law of 1864 , because it eliminated articles 414 to 416 of the penal code, articles which had constantly imperiled both the existence of unions and the right to picket.

However, two doctrinaire liberals, anxious to retain articles 414 and 4 I 5 of the code, introduced an amendment to this effect. Ribot and Trarieux insisted that some sort of legal restraint was needed against workers who resorted to violence. The amendment passed. No public vote took place, but the Radicals had for a long time opposed practically all legal restrictions on lay associations. Unless they violated their deep-rooted libertarian tradition, they voted against this measure. The vote, however, registered the true temper of the Chamber. Articles 4I4 and 4Is were retained when the bill came up for its second reading on June 9. The result was that individual workers, when on strike, were practically at the mercy of the courts which interpreted the code, and the courts were not friendly to labor. Moreover the failure of Cantagrel's amendment left unregistered unions subject to articles 291-294 of the penal code and other measures which had been passed to restrict trade union activity.

For this reason La Justice of Clemenceau continued to demand full freedom for worker organizations and proposed a model statute:

"Proposition de Loi

Article Premier

Le travail est libre. Chacun a le droit de disposer de son travail et d'en discuter les conditions, soit individuellement, soit par voie de concert, en quelque nombre que ce soit, sous la simple observation des lois de droit commun.

Art. 2

Les articles $4 \mathrm{I} 4,4 \mathrm{I} 5$ et $4 \mathrm{I} 6$ du Code Pénal sont abrogés.

Art. 3

La présente loi est applicable à l'Algérie et aux colonies." 1

The Radical-Socialists, after the amendment of Cantagrel, did not take an active role in the debates on the bill. They voted against efforts to restrict further the right of unions, but so did the majority of deputies, so that limiting amendments were defeated. In its second reading on June 9, the bill had easy going.

The Senate, however, disfavored many of its provisions. It came back to the Chamber in 1883 , and debate began once more. On

${ }^{1}$ March 23, I 882, p. I, cols. 5-6. 
June I6, Edouard Lockroy took up the challenge. The Senate, he argued, refused to permit federations of unions, or the existence of nonregistered ones, and had restored article $4 \mathrm{I} 6$. The Senate, therefore, was in opposition to the Chamber. Lockroy played up this opposition, because the extreme Radicals had as part of their political program the Senate's demise. That body, due to its electoral origin, was against reform; it represented rural backwardness. Because the bill afforded special rights to duly organized workers, it was seeking to destroy these rights. Lockroy had voted for Cantagrel's amendment in $188 \mathrm{I}$; now, two years later, he came closer to Nadaud's reasoning: workers needed special legislation. Lockroy had come to realize that full freedom of association was not feasible in an opportunist Chamber; also, he clearly recognized that large-scale industry had created special conditions: "Je dis que ce fut une situation spéciale que l'on créa alors aux hommes de labeur, à ces travailleurs, à ces ouvriers, que la multiplicité de la production, que la facilité des transports, que la création des machines, que l'acharnement de la concurrence condamnèrent aussitôt et d'une manière normale au chômage et à la misère! Je dis qu'ils se trouvèrent dans une situation spéciale et exceptionnelle, entre le bourgeois, que l'industrie avait fait riche, et le paysan, que la Révolution avait fait propriétaire." ${ }^{1} \mathrm{He}$ concluded with the belief that unions would help bring about industrial peace. Workers are not given to violence; they are mature and able to discuss their own affairs. The distrust of the Senate is baseless. He was supported by his colleague, Brialou who said: "Soyez bien certains, messieurs, que plus vous donnerez de vie et de liberté aux syndicats professionnels, plus vous faciliterez l'accord et l'entente entre le capital et le travail, qui apprendront à mieux se connaître et à mieux s'apprécier mutuellement." 2

Undoubtedly the arguments of Waldeck-Rousseau, Minister of Interior, in defense of the Chamber's original bill had greater weight with moderates. The original bill passed again and went up to the Senate. There Waldeck-Rousseau, Corbon and Tolain championed it and the right of federation won out by seven votes. Article 416 was also dropped, but since other changes were made, chiefly in regard to registration, the bill returned to the Chamber where it was debated once more.

Even before the bill came back to the lower house, many left-wing Radicals began to have second thoughts about it. Clearly the bill

1 J.O., June 16,1883 , p. 1315 .

2 Ibid., June 18,1883 , pp. 1334-39. 
would pass. But what would now be the position of unregistered unions? This was the question Clemenceau asked on January 30, I 884. Patently he was not enthusiastic about the bill: "Cette liberté des chambres syndicales, telle qu'elle va revenir du Sénat après les derniers votes, ne sera pas encore la liberté, ni même une portion de la liberté d'association; car vous ne déterminerez pas l'ouvrier des villes à aller préalablement se faire inscrire au parquet et à la préfecture de police. Ce sera là une aggravation du régime actuel, et non pas une amélioration. Ce sera une liberté sur le papier, mais pas la liberté agissante . . .; vous n'aurez pas agi sur la société ouvrière; vous ne l'aurez dotée d'aucune liberté: vous aurez apporté des restrictions à l'état de choses actuel, vous aurez proclamé un droit théorique, dont vous aurez empêché l'exercice par la menace de l'ingérence de la préfecture de police." 1

This was precisely the point of keen debate during March. Clemenceau insisted that registration and the listing of the names of union officers was a great danger for the workers. The state was on the side of employers and would use the lists to oppress labor leaders. ${ }^{2}$ Cantagrel returned to the attack. His opinion was that the Senate did not even give workers an option between registering to obtain legal recognition or not registering to enjoy toleration; unions must register or dissolve. After a vigorous attack on the other house he urged the Chamber to send its original bill back there. This proposal was rejected by secret vote. ${ }^{3}$

This vote did not dispel the confusion resulting from the Senate's amendments. René Goblet, who was a moderate republican at this time but who became a Radical-Socialist in the I $890^{\circ} \mathrm{s}$, held the same interpretation as Cantagrel. The reporter, Legrand, insisted that nonregistering syndicats would disappear as syndicats; they would not be defined in law and simply exist under a system of tolerance. Evidently he was not troubled by the distinction; he blandly assumed that no serious trade union would refuse to make known its statutes. After him Jules Ferry stated that nonlegal unions would be tolerated. Despite the attempts of Goblet and Clemenceau to introduce greater clarity into the bill, it passed its final reading and became the law of 1884 .

The trade union congress which met in Lyon in 1886 condemned the new law. It proposed the following text: "Article premier. Les ouvriers de toutes corporations sont autorisés à se syndiquer et les syndicats à se fédérer. Article 2. La déclaration de leur constitution à

1 Jbid., Jan. 30, 1884 , p. 254.

2 Ibid., March I 3,1884 , p. 742.

3 Ibid., pp. 738-39. 
la mairie de leur commune leur constitue la personalité civile." 1 This was practically the position of many Radical-Socialists.

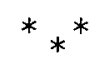

The law of 1884 provided for unions at the local and national levels; as yet public opinion was distrustful of international organization. The Radicals, who were ardent patriots, who had fought desperately against the Germans in 1870 and denounced the Treaty of Francfort, who for awhile were filled with the spirit of revanche, were none the less the rare defenders of the First International before and after the Commune. They did not belong to it, and few were the workers among their ranks in the National Assembly. However, when Thiers' government put forward a bill to outlaw it, they rallied to its defense. Gambetta's République française denied that it was subversive. An editorial deplored the fact that employers knew practically nothing about the social conditions and aspirations of their workers. It was their ignorance which caused them to view the International as an enemy. ${ }^{2}$

When debate began on Thiers' bill in March i 872, Louis Blanc took up the cause of workers in all countries. That their unity transcended frontiers did not constitute subversion. Among those liberties which all men might claim was the right of association at all levels, from the local to the international. In their press the Radicals carried their campaign to the public, a very limited public as yet. In Le Radical Sigismond Lacroix wrote: "La révolution sociale par la liberté politique et par la fédération des peuples, tel était le programme des serviteurs de l'idée nouvelle." The International " $n$ 'est autre chose que la mise en oeuvre de ce programme, . . . un effort digne d'admiration vers un but légitime." ${ }^{3}$ La Justice, a short-lived radical sheet, was also a vehicle of defence. When the bill became law, Robinet wrote in it, "Il n'y a plus de droit." 4

Most left-wing Radicals managed to combine varying degrees of distrust of Germany and a strong commitment to the ideal of European federation as preached by Victor Hugo. The Workingmen's International, even after its demise, seemed to them a first step in the right direction. In December i88 I Le Radical disapproved the labor

1 Montreuil, p. I34.

2 Nov, I4, I 871, p. 2, cols. 5-6.

3 March 2, 1872, p. I, col. I. See March 7, p. I, cols. I-4.

4 March 19, 1872, p. 1, col. 1. Not to be confused with Clemenceau's paper founded in 1880. 
congress of Paris when its majority killed a motion against Thiers' law. The journalist believed that these worker delegates were trying to placate the Senate before whom was the bill on trade unions. This tactic, he warned, was an error. The Senate must be destroyed, not placated; anyway the bill was not a good one. But worse, the vote against the motion threatened the European solidarity of workers and, therefore, their emancipation. ${ }^{1}$

The next year Stéphan Pichon reproached Jules Simon with hypocrisy. Simon was Senate reporter on an association bill, and in his report stated that he favored all associations save international ones. For Pichon, the aim of this bill was clear: to grant rights to religious orders that it would deny to workers. Simon "n'a pas assez de ménagements pour les congrégations religieuses." "La liberté avec une exception', dites-vous, 'ce n'est plus la liberté, c'en est le contraire, c'est le privilège.' " Simon's own words, then, condemned his exclusion of international unions. As for the Radicals, concluded the journalist, "Ce que nous voulons, c'est la liberté pour tout le monde." 2

The international ideology of left-wing Radicals was directly connected to their desire for freedom of trade and their demand for more equal social conditions among workers of different countries. Clemenceau, probably the most revanchiste of the Radical-Socialists, argued in the Chamber that international trade unions would benefit French workers. Labor solidarity transcending frontiers would encourage the rise of salaries everywhere and prevent French entrepreneurs from importing cheap labor. ${ }^{3}$

Despite their efforts, the law of 1872 was not abrogated until July $190 \mathrm{I}$ when parliament passed a general bill on associations. By this time, however, the Radicals were something less than enthusiastic about international labor movements. Many equated internationalism with the anti-patriotism of the revolutionary Syndicalists.

$$
\text { ** }
$$

With the sincere fervor that the left-wing Radicals championed trade unionism, they took up the defense of the Bourse du Travail in Paris. This Bourse (not to be confused with the stock exchange) was a kind of labor headquarters. In 1886 Gustave Mesureur (RS) put forward a bill for its creation. As conceived by him and by left-wing Radicals,

1 Dec. I 2, I881, p. I, cols. 5-6.

2 La Justice, July I I, I 882, p. I, col. I. The Radicals were hardly in favor of freedom for religious associations, at least as long as the state supported the church.

3 T.O., Jan. 31,1884 , p. 257. 
as well as by Socialists and Syndicalists, the Bourse du Travail was a means of enlarging the role of all trade unions by providing them with meeting and lecture rooms, offices and an employment bureau. Mesureur was president of the Paris Municipal Council when the building was inaugurated the next year. To the workers assembled he said simply, "Vous êtes ici chez vous."

By the I $890^{\circ}$ 's the conservative and moderate republicans were not of this opinion. Charles Dupuy, when he became Premier in 1893 , accused the Syndicalists of using the Bourse as a center of revolutionary propaganda. They therefore violated the law of I 884 which forbade trade unions to discuss politics and religion. In addition, he complained that unregistered groups were meeting there. Since the Bourse had been declared of public utility, it must be reserved exclusively for labor unions with the civil personality acquired by fulfilling the 1884 law. Therefore when violence broke out during the May Day celebration of 1893 , he ordered the police to close the building. A Socialist deputy, Baudin, complained that he was a victim of police brutality.

In the Chamber and in their press the Socialists as well as the Radical-Socialists vehemently condemned Dupuy, and the former interpellated him. They demanded an inquiry into the charges of Baudin. Millerand posed an order of the day to this effect. Dupuy, however, accepted only a pure and simple order of the day. That he emerged victorious was not surprising; 305 deputies voted for him, I 6 against. The latter was a protest vote, including left-wing Radicals, left-wing Nationalists and Socialists. Thirty out of thirth-six RadicalSocialists voted in the negative while four abstained. Eight social Radicals voted against while most of the remainder abstained. Only two of them joined the majority of orthodox Radicals who followed Léon Bourgeois in voting for the cabinet. ${ }^{1}$

That the Radical-Socialists stood by labor in a crucial vote was not unusual. Certainly they opposed Dupuy for many reasons other than his social policy; but they did not side with the workers because they were against a conservative Premier. Their long pro-labor record hardly supports such an assertion. The fact is, most of them never did accept the law of 1884 in its entirety. They continued to proclaim that nonregistered unions must enjoy the same freedom of action and immunity as registered or legal unions. A good example of their views may be found in a leader by Ernest Lesigne in Le Radical. He defended those labor leaders who put themselves "sous un régime supérieur à toutes les lois d'occasion, sous le régime réclamé de tout

1 Ibid., May 2, 1893, p. 1328. 
temps par tous les républicains, sous le régime du droit d'association pour tous les citoyens.

"Les ouvriers se sont donc souvenus qu'ils étaient aussi des hommes, des citoyens et ils se sont groupés en vertu des droits de l'homme et du citoyen, proclamés par la bourgeoisie elle-même . . .

Par conséquent, les syndicats sont devenus des sociétés comme toutes les autres, où l'on parle de ce qu'on veut, parce que c'est le droit; mais où cependant on s'occupe presque exclusivement des conditions économiques faites aux travailleurs, parce que c'est de là que vient la souffrance et la misère de notre génération." 1

Dupuy's reason for closing the Bourse, the Radical-Socialists insisted, was not legitimate. Camille Pelletan attributed most sinister motives to him. "La police tue un innocent. Cela ne suffit pas. Il y a quelques jours de désordre, soigneusement aggravé par les Blouses Blanches (agents provocateurs). Mais l'ordre finit par se rétablir. Quelle affreuse population! On assomme les passants; on tue les consommateurs aux portes des cafés; on force l'entrée des hôpitaux pour cogner sur les médecins et les internes et on n'obtient pas la plus petite émeute. Alors, on fait mieux. On ferme la Bourse du Travail ... Il y a là une agression caractérisée contre les libertés et les intérêts de ces travailleurs pour lesquels on étale, en paroles, un zèle si exorbitant." " Le Rappel and La Petite République indicted the cabinet in the same grand manner.

The Casimir-Perier cabinet succeeding that of Dupuy kept the Bourse closed. Raynal, Minister of Interior, asserted that the tolerated unions had defied his order to register if they wished to use the Bourse, and that the general committee of the Bourse encouraged them in their defiance. Establishments of public utility might be used only by legally constituted bodies.

On February 10, I 894 Pelletan interpellated Raynal. He and several Socialists accused the cabinet of refusing to grant trade unions the rights it accorded to nonauthorized religious groups. Since all governments had tolerated nonlegal unions, Raynal's defense was not sound; he did not have any right to keep the Bourse closed because of the presence of these unions. Once more the government accepted only the pure and simple order of the day. The vote was 350 for, 155 against. ${ }^{3}$ The line up of votes was similar to that on May 2 of the previous year. But now the Radical-Socialists were entirely opposed, as were the social Radicals, with one abstention. Most orthodox

1 Feb. 23, 1893, p. I, cols. 2-3.

2 La Justice, July 7,1893 , p. I, cols. I-2.

3 J.O., Feb. 10, I 894, pp. I 87-88, I 9 I. 
Radicals followed Bourgeois, but a larger number of them, strong on syndicalism although weak on social legislation, such as BovierLapierre, joined the opposition.

Despite his vote, Léon Bourgeois, when he became premier in December 1895 , opened the Bourse. This act was heartily greeted by all left-wing Radicals. ${ }^{1}$ They considered the act indicative of a "truly republican" administration. Truly republican came to mean a democratic regime friendly to labor, and with no enemies on the left.

$$
* *
$$

Their common struggle for trade union laws had brought left-wing Radicals and parliamentary Socialists closely together. This alliance was further tightened by their discovery that legal recognition, whatever it might do for unions, did not protect individual members from arbitrary dismissal by employers. As long as employers had the right to fire workers who joined a union, the right of unionism, regardless of the 1884 law, did not exist.

Radical-Socialists had long insisted that the real enemy of unionism was a hostile management. Now these Radicals were not proponents of class conflict; on the contrary, their ultimate goal was the reconciliation of labor and management through arbitration. Hostility to unions, they agreed, was not common to all employers. Yet, their prevailing attitude was that big entrepreneurs, especially the directors of mining companies, were determined to destroy syndicalism. This they recognized before the passage of the 1884 law. In their opinion the I 864 law permitted workers to organize. Therefore not the absence of a better law but the fairly general hostility of capitalists was the chief obstacle to the labor movement. La Justice pointed this out in 1880 . The ébénistes (furniture makers) were on strike, demanding higher wages. Workshop owners resorted to the yellow-dog contract in clear violation of the law's permission to form coalitions. ${ }^{2}$ The strike was broken, so was the union.

That union breaking was illegal became a constant theme of the Radical-Socialists. To those who stated that all labor need do, to defend itself, was form trade unions, Clemenceau sarcastically remarked that in order to organize, the workers must be free. Clearly they were not. He studied the conditions of the miners at Grand' Combe and Bessègues in the Gard. There it was a regular practice for companies to fire labor leaders. There it was management who was

1 Le Radical, Dec. I I, I895, p. I, cols. I-2.

2 Sept. 29, I880, P. I, cols. 5-6. 
united against the workers, and who, on occasion, went on strike against the unions by resorting to lockouts. These miners, victims of "la grève des patrons", described to the deputy the fate that awaited them should they try to organize. Naturally they were fired, but worse, "nous perdons l'argent que nous avons versé à la caisse des retraites et on refuse de nous employer dans d'autres mines." The worker, Clemenceau went on, had no more freedom to form a coalition than had medieval serfs. The mining companies in the Gard basin, for example "ont accaparé . . . la vie entière de l'ouvrier; elles le logent, le vêtissent, le nourrissent au moyen des magasins généraux; elles lui fournissent les soins médicaux, la pharmacie, elles tiennent complètement l'ouvrier, elles sont maîtresses de son labeur, de sa vie, elles le tiennent par la retraite, qu'il paie de ses deniers et qu'il perd s'il est renvoyé, eût-il travaillé pendant vingt, vingt-cinq ans au service de la Compagnie, qui peut le mettre à la porte, sans explications, sans motifs. Il est complètement dans la main de la Compagnie par le crédit qu'il obtient des magasins généraux. Le salaire du premier mois est retenu par la Compagnie, comme une sorte de cautionnement, et ce n'est qu'à la fin du second mois que l'ouvrier touche sa paie pour la première fois. Il est donc obligé de vivre sur le crédit que lui fait la Compagnie, et, une fois endetté, il ne peut plus se libérer." 1

Clemenceau scoffed, in his biting sarcastic way, at all the talk of the "liberté du travail". In I 884 he and Germain Casse made a study, as members of a parliamentary committee, of conditions in the Anzin coal basin. His report was a long indictment of the Anzin Mining Company's labor practices. Here is a selection from it as it was summarized in La Justice:

"Le syndicat des mineurs du Nord, ses statuts en font foi, avait bien pour objet l'étude et la défense des intérêts économiques de ses membres.

Mais la Compagnie d'Anzin estima qu'elle ne pouvait, à aucun prix, en supporter l'existence. La discussion entre les mineurs et les ingénieurs sur les conditions du travail paraissait inadmissible à la Compagnie. Si les lois sur les prud'hommes et les délégués, corollaires indispensables, pour les ouvriers mineurs, de la loi sur les syndicats professionnels, avaient été votées par le Sénat, c'en était fait pour toujours du système de soumission absolue et d'obéissance passive que les Compagnies prétendent, dans toutes les questions, imposer aux ouvriers.

1 La Justice, March I1, 1882, p. I, col. 3 . 
Aussi, les Compagnies menacées dans leur omnipotence par le vote imminent de ces lois ont-elles couru au plus pressé. Elles ont rendu impossible le fonctionnement des syndicats ouvriers. Il leur a suffi de renvoyer impitoyablement tous ceux qui avaient pris part à l'organisation et à la direction du mouvement syndical. $\mathrm{La}$ persécution fut si ardente que les cotisations des ouvriers syndiqués ne purent même pas être perçues dans les corons. Quelques obstinés versèrent d'abord leur cotisation 'en cachette', avec mille précautions, puis finirent par y renoncer.

Ainsi une loi votée par la Chambre et le Sénat, promulguée par le Gouvernement, est nulle et non avenue. Les bénéfices de la loi sur les syndicats sont perdus pour les ouvriers mineurs.

Voilà qui est surabondamment établi par l'enquête de votre délégation.

Lorsque la Chambre adopte une loi spéciale aux ouvriers mineurs, les Compagnies demandent pourquoi on leur applique des lois d'exception.

Lorsque la Chambre vote une loi générale telle que la loi sur les syndicats professionnels, les Compagnies en empêchent l'exécution.

L'Etat a le devoir d'intervenir, nous avons démontré qu'il en a le droit.

Comment cette intervention peut-elle s'exercer?

Le droit d'intervention en cas de grève pourrait s'exercer en se fondant sur certains articles de la loi de i 8 го, sur l'article 49 notamment, qui admet le retrait de la concession d'une mine lorsque l'exploitation est restreinte de manière à inquiéter les besoins des consommateurs.

Les orateurs du gouvernement qui défendirent la loi de 1838 à la Chambre des pairs firent triompher, rappelons-le, ce principe que le concessionnaire qui laisse la mine exploitée dans des circonstances qui entraînent une souffrance réelle de la part des consommateurs, manque au premier de ses devoirs ...

L'Etat peut donc immédiatement agir. Une nouvelle circulaire ministérielle peut modifier les circulaires et les instructions anciennes, et, en tenant compte de toutes les circonstances, sauvegarder les intérêts de l'Etat. Ce qu'une circulaire ministérielle a accordé, une circulaire ministérielle peut le reprendre. Plus l'Etat a comblé les compagnies de faveurs, plus elles se sont montrées intraitables; nous sommes convaincus que lorsqu'elles se trouveront en face d'une administration équitable mais ferme, et absolument résolue à faire prévaloir l'intérêt social sur l'intérêt privé, elles se soumettront de bonne grâce et renon- 
ceront à l'exorbitante prétention d'être un Etat dans l'Etat. Mais il faut viser plus loin; la loi de i 8 Io n'a jamais été amendée qu'en faveur des Compagnies, elle doit être complètement révisée. Nous croyons qu'il faut revenir au régime de la loi de I79r. C'est-à-dire au principe de l'aliénation temporaire du domaine national (concession directe ou adjudication).

Les contrats de concession du domaine national doivent donc être révisés, et les cahiers des concessionnaires muets jusqu'ici sur les rapports économiques des compagnies et des ouvriers doivent être mis en harmonie avec le principe de la justice sociale. Alors même que le principe de la concession perpétuelle serait maintenu, on pourrait par exemple imposer aux compagnies le système de la participation aux bénéfices. Le droit de l'Etat à cet égard n'est pas douteux; il est évidemment libre de déterminer les conditions auxquelles il lui convient d'aliéner temporairement le domaine national.

Le même raisonnement s'applique en ce qui concerne les chambres syndicales.

Dans l'industrie privée, lorsque les syndicats patronaux entreprennent la lutte contre les syndicats ouvriers, l'Etat n'a pas de moyens d'intervenir, et c'est aux ouvriers qui sont le nombre qu'il appartient de se grouper pour la résistance. Mais dans l'industrie créée par une concession d'une part du domaine national, il appartient à l'Etat de fixer d'avance les droits des parties et de les faire respecter.

Le droit des chambres syndicales de discuter les intérêts de la corporation résulte de la loi générale. Il n'est pas admissible que des industriels qui tiennent leur fortune d'une concession d'Etat enlève à toute une classe de citoyens les bénéfices de la loi, et cela avec la complicité plus ou moins avouée de l'Etat.

Nous croyons qu'on doit introduire dans le cahier des charges une clause aux termes de laquelle, lorsqu'il résultera d'un ensemble de faits qu'une Compagnie aura systématiquement empêché l'établissement ou poursuivi la suppression des chambres syndicales, il y aura lieu à sanction pénale." 1

The cabinet did not agree with Clemenceau's interpretation of the laws governing mining concessions. There existed no legislation giving it power to act. Tony Révillon raised this issue again when a strike occurred in the Ardennes. A private company was involved. Allain-Targé, champion of the I 884 law, assured him that the cabinet

${ }^{1}$ Nov. II, 188 , p. 2, cols, 2-3. 
reproved all employers violating the rights of labor; but "le Gouvernement en pareille matière n'a qu'un pouvoir moral, un pouvoir de conseil, de blâme à cette tribune; en dehors de cela, il est désarmé . . . Nous sommes donc sous le régime de la liberté."

To this Révillon replied: "Vous avez parlé de la liberté du travail, monsieur le ministre; mais vous savez comme moi qu'être libre, c'est pouvoir, et que les patrons, quand même le chômage les force pendant quelques jours de fermer leurs ateliers, ne manquent pas de pain pour leurs femmes et leurs enfants, tandis que les ouvriers, au contraire, ne peuvent pas se passer de travailler. Pour les priver de leur travail, il faut qu'on leur donne une raison plausible, valable. Est-ce une raison que de dire: Vous usez de la loi, vous vous syndiquez; eh bien, nous vous chassons, nous vous mettons sur le pavé, nous vous enlevons votre pain et le pain des vôtres?" 1 This was Louis Blanc's definition of liberty as the power to act rather than as an abstract right. Révillon protested against the cabinet's views, but he could not force it to intervene in the worker's behalf.

Most republicans were not in full agreement with Révillon who, after all, was a hard core Radical-Socialist, whose voting record was more consistently in favor of basic reforms than those of several Socialists. But a majority of republicans, including most Radicals, were outraged by the authoritarian behavior of many employers. That some of these employers were monarchists and clericals undoubtedly influenced their views. It is not surprising, therefore, that there was a majority for the Bovier-Lapierre bill, introduced in the Chamber in I886. It provided a fine or imprisonment or both if an employer fired his workers for organizing. Bovier-Lapierre was a moderate Radical whose voting record on social matters is rather unimpressive. Nonetheless his bill failed in the Senate. The opposition argued that it was too one-sided, being directed solely against management. He reintroduced it in 1890 when it was revised so as to make it bilateral. As three years earlier the Radicals voted against amendments to weaken it further. They also voted against an amendment of the Socialist Jourde, that would have imposed extremely heavy penalties upon employers. Clearly even the Radicals were trying to placate the Senate. That body, however, was not moved and killed the measure a second time.

Encouraged by the Radicals, Bovier-Lapierre reintroduced his bill in 1892. On this occasion Georges Leygues, a conservative republican, asserted that workers were protected by recent court decisions against 
arbitrary dismissal. What France needed, rather, was a bill to protect workers against the tyranny of trade unions. He proposed an amendment extending the bill's penalties to labor coalitions which used force or threats either to sign up workers or to prevent them from quitting. His amendment was offered as paragraph 2 to article $\mathrm{I}$.

The Radical-Socialist Paul Doumer opposed it. He argued that Leygues could point out merely one example of arbitrary union action, an example hardly worthy of merit because dissident workers had formed another union. There were, however, numerous examples of employers destroying worker organizations. The amendment would turn the bill against organized labor in need of protection. Doumer went on to berate the Senate and concluded: "A l'heure actuelle, je crois que la Chambre doit faire une sorte de manifestation qui ne sera pas platonique ... .; elle doit dire si elle entend que la volonté du suffrage universel soit obéie." 1

At first Bovier-Lapierre opposed Leygues' innovation, then, on April 2, he rallied to it. The Senate now would receive the bill more favorably. The extreme Left, however, insisted that the bill was bilateral already, that the amendment would encourage attacks upon organized labor. Returning to the original article $\mathrm{I}$, two Socialists presented it as an amendment to the amended article I. Only 147 deputies voted for this: fifty-three left-wing Radicals, the Socialists, and left-wing Nationalists. Three hard core Radical-Socialists and one Radical-Socialist abstained; one social Radical did the same, and five of them voted in the negative.

The large negative vote was simply a refusal to favor a measure sponsored by Socialists. When the Leygues amendment came up, it was soundly defeated, I 29 for, 288 against. A few moderate Radicals, Léon Bourgeois, Viette, Jamais, voted for it. The left-wing Radicals were solidly against it. The entire bill finally passed, 267 for, 215 against. The favorable vote had fallen from 344 in 1890 , and the unfavorable had risen from 142. The Senate again killed the measure, encouraged, if that was necessary, by the relatively slim vote.

Left-wing Radicals continued to agitate in their press for legislation to protect organized labor. After his electoral defeat in 1893 , Clemenceau was particularly active - and particularly vehement. At Anzin, he wrote in La Justice, the company had succeeded in preventing the formation of a union. Elsewhere weak organizations had been set up, calling themselves unions, despite constant threats and reprisals from management. "Ce que ces fragments informes de syndicats ont coûté

Ibid., March 19, 1892, pp. 307-17; p. 317 for quotation. 
de larmes, infligé de misères, suscité de haines, on ne le saura jamais." 1 Le Radical also was bitter in its denunciation of conditions at Anzin where the mining company had become a state within the state. "Il faut être avec la Compagnie ou ne pas être." This was what Dupuy called "la liberté du travail". 2 The Senate was directly responsible for this situation. "De par la volonté du Sénat, les patrons de la mine continueront impunément d'attenter à la liberté de leurs ouvriers. C'est le triomphe de la liberté du plus fort. Avant la République, on appelait cela l'oppression." 3

By the mid-1 890's the basic weakness of the trade union law was manifest. A decade earlier most Radical-Socialists, led by Cantagrel, had demanded a general law on association, and one susceptible of enforcement. What had passed was a special law without penal sanctions, and therefore not susceptible of enforcement. By 1895 the politicians in power opposed sanctions. Georges Leygues, Minister of Interior, explained, "La loi sur les syndicats n'est pas une loi d'intérêt public, d'ordre général, à laquelle doit être nécessairement attachée une sanction pénale." " He made this statement when explaining his opposition to an order of the day of Sembat. The Socialist had called upon the cabinet to prepare a bill containing penalties for violators of the trade union act. This issue had been raised once more by a strike at Roanne where unionists had been fired en masse. The cabinet accepted only the pure and simple order of the day, and it was supported overwhelmingly, 387-102. The negative vote was chiefly Radical-Socialist and Socialist. Five of the former voted for the cabinet, one abstained. Nine social Radicals voted for, six abstained. Over half of the social Radicals, then, supported a socially conservative government, either directly by voting for it, or indirectly by not voting against it.

However, when the Bovier-Lapierre bill came up again in November 1895, Radicals of all shades voted for it. And when Léon Bourgeois became Premier his government drew up a similar bill. ${ }^{5}$ Unfortunately he resigned before it came up for debate. Neither it nor the Bovier-Lapierre project ever became law.

$$
* *
$$

When the Senate killed the first Bovier-Lapierre bill, it is probable that left-wing Radicals and parliamentary Socialists were already

1 Nov. 13, I 893, p. I, col. 1.

2 Sept. 29, 1893. p. I, col. 6.

3 La Justice, Nov. 13, 1893, P. I, col. I. See also Le Rappel, Oct. 8, I895, p. I, cols. I-2. 4 J.O., Feb. 23 , I 895 , p. 546.

5 Ibid., Nov. 21 . 1895, pp. 2442-44; Feb. 4, 1896, p. 167. 
searching for another method to safeguard unions. The i 884 law excluded from union membership persons no longer exercising the craft. An amendment permitting such persons to remain in their union, even to become officers, would increase the independence of the union vis-à-vis employers who fired officers in order to destroy it.

Many labor coalitions had long violated the law by doing precisely this $-90 \%$ of them according to Basly. But when Fallières became Minister of Justice in $189 \mathrm{I}$, his administration began proceedings against the metallurgists of Maubeuge; their coalition was dissolved. ${ }^{1}$ Despite this action, he proposed a bill to modify the 1884 law. Persons who had exercised a trade during five years, and who had not ceased to practice it for over ten years, might remain in the union. Debate began in November 1892 . The Socialist Lamendin opposed the ten year limitation. Paul Doumer strongly supported him. The ten year clause passed, 383-1 IO. The negative vote was cast chiefly by RadicalSocialists and Socialists. Social Radicals tended to abstain. Some outstanding Radical-Socialists, however, voted for: Chautemps, Maret, Henri Mathé, Révillon and Salis. The entire project passed but was killed in the Senate, ${ }^{2}$ the graveyard of serious social legislation.

When a similar bill was drawn up in June 1894 , a new legislature was in power. The 1893 elections had been a moderate success for RadicalSocialists whose number rose from 36 to 48 . The Socialists also increased their strength. Encouraged, Sembat proposed an amendment. It would permit both workers and employers, who no longer carried on the trade, to join their respective unions, even if they had not been members. It also allowed them to remain in their unions after retirement if they had already been members. Strongly opposed by both the cabinet and a majority of the labor committee, the measure failed, I77-33I. Only this time practically all the Radicals, even Léon Bourgeois and Gustave Rivet, voted for. ${ }^{3}$

Essentially this same Radical and Socialist vote was counted against an amendment of Léon Guillemin, which would prohibit from membership any worker who left the trade and exercised another: Guillemin said his amendment was designed to prevent café owners and deputies from entering union administrations. These people encouraged strikes and political action among workers. ${ }^{4}$ Clearly his measure was aimed against laborite deputies such as Basly. Dupuy readily supported it and it passed. An amendment was added stating

1 Ibid., June I, I 891, pp. 1074-76.

2 Ibid., Nov. 3, 1892, pp. 1402-7.

3 Ibid., June 14, 1894, pp. I01 2-13, 1023.

4 Ibid., p. IOI 7 . 
that workers who did not voluntarily leave the profession, who were fired, for example, could legally remain in the union. There was no public vote.

But paragraph 4 of article 4 of the committee's bill allowed only one third of the administrators in a union te be chosen from workers out of the trade. The Socialist Groussier declared from the rostrum that this measure would leave two thirds of the leadership defenseless, and therefore labor coalitions would still be vulnerable. The paragraph passed, 380-1 34. The negative vote was chiefly left-wing Radical and Socialist. This same line up, plus some moderate Radicals, supported another amendment of the Socialists: The two thirds restriction would not be applicable to union leaders forced to leave the trade (dismissed) during their period in office. The vote was $\mathrm{I}_{4}$ for, 334 against. ${ }^{1}$ These several proposals which would have afforded a measure of protection to labor were defeated. Employers continued to fire unionists and Radicals continued to complain of it. ${ }^{2}$ No effective law existed to change the $\mathrm{I} 884$ act into anything other than an abstract right. Historians have explained the weakness of French syndicalism as a result of Gallic character, of small scale industry, of the revolutionary tradition and so on. We suggest here that there is need for a closer study of syndicalist legislation and governmental policies in order to round out the explanation. It is interesting to note that most left-wing Radicals, until about 1900 , acted on the belief that the weakness of syndicalism lay not in the unwillingness of workers to organize, or in their stinginess when called on to pay dues, but in the hostility of employers and the inadequacy of legal safeguards. The relative impotency of unionism necessitated more laws of a nature to encourage its growth. Not until after 1900 did Radicals become increasingly critical of the workers themselves.

2 See, for example, Le Rappel, Oct. 8, I 895, p. 1, cols. I-2. 